Proceedings of SALT 29: 103-116, 2019

\title{
Types of pluractionality and plurality across domains in Pay?ajuӨəm*
}

\author{
Gloria Mellesmoen \\ University of British Columbia
}

\author{
Marianne Huijsmans \\ University of British Columbia
}

\begin{abstract}
In this paper, we examine two markers of verbal plurality, $\mathrm{C}_{1} \mathrm{C}_{2}$ reduplication and ablaut, in Pay?ajüəm, a Central Salish language. $\mathrm{C}_{1} \mathrm{C}_{2}$ reduplication marks event external pluractionality, where subevents are distributed in both space and time. It also applies in the nominal domain creating a plurality of individuals, but does not impose temporal or spatial distribution in the nominal domain. Following Henderson $(2012,2017)$, we propose that events are individuated through their temporal and spatial traces, so that events distribute in order to pluralize, whereas this is not required in the nominal domain. Ablaut marks event-internal pluractionality where subevents are grouped into a larger whole (Wood 2007; Henderson 2012, 2017). While ablaut pluractionals typically involve numerous subevents that are closely spaced in time, they can involve as few as two subevents and do not require strict adjacency of all subevents. We propose that they denote an atomic group event that is mapped to a plurality of events via a membership function (Barker 1992). This contrasts with event-internal pluractionals that require a high number of temporally adjacent subevents and have been analyzed as being grouped through their temporal configuration (Henderson 2012, 2017), indicating that there is more than one way to group events, just as there is more than one way to group individuals in the nominal domain (Barker 1992; Henderson 2012, 2017)
\end{abstract}

Keywords: Salish, pluractionality, plurality, grouping

\section{Introduction}

Pay?aju0əm (Comox-Sliammon) is a Central Salish language spoken in BC, Canada, with approximately 47 L1 speakers (First Peoples' Cultural Council 2018). In this paper, we focus on two markers of plurality that occur on verbs: $\mathrm{C}_{1} \mathrm{C}_{2}$ reduplication

* We are deeply grateful to the PayPajuӨəm speakers we work with: Joanne Francis, Elsie Paul, Freddie Louie, Karen Galligos, Betty Wilson, Marion Harry, Margaret Vivier, Jerry Francis, Phyllis Dominic, Maggie Wilson, and Mary Harry. We also thank members of the TAP Lab and the Salish Working Group, particularly Henry Davis and Lisa Matthewson, for insightful feedback and support. This project is supported by the Jacobs Research Fund and a SSHRC Insight Grant (435-2016-1694) awarded to Henry Davis. 
and ablaut (Watanabe 2003). We argue that $\mathrm{C}_{1} \mathrm{C}_{2}$ reduplication marks event-external pluractionality, while ablaut marks event-internal pluractionality. $\mathrm{C}_{1} \mathrm{C}_{2}$ reduplication may also indicate plural individuals when it is applied in the nominal domain, providing morphological evidence for parallelism in the expression of plurality across the nominal and verbal domains (e.g. Krifka 1989, 1992; Landman 2000; Lasersohn 1995; Link 1998). In both domains, we argue that $\mathrm{C}_{1} \mathrm{C}_{2}$ reduplication indicates a plurality of atoms, but these atoms are individuated through distribution in time and space in the verbal domain. In contrast, plurals formed with the ablaut process involve multiple subevents grouped into a single event. This type of grouping is a defining quality of event-internal pluractionality (Wood 2007; Henderson 2017), though the ablaut process does not exhibit many characteristics generally associated with event-internal pluractional markers. We propose that there is more than one way to group events, just as there are different ways of grouping individuals (e.g. Barker 1992; Henderson 2017). Both the event-external $C_{1} C_{2}$ reduplication and the event-internal ablaut process, when examined in detail, provide new evidence for parallelism in the expression of plurality across the nominal and verbal domains.

\section{Distribution of $\mathrm{C}_{1} \mathrm{C}_{2}$ reduplication and ablaut}

When unmarked for plurality, nominal and verbal predicates in Pay?ajüəm may have either singular or plural reference. In (1), the volunteered descriptions of a picture of two cats involved a singular noun in one iteration and a plural noun in another. Similarly, in (2), both the singular form of the verb and the plural form of the verb were volunteered to describe a plurality of closing events in the same context. ${ }^{1}$

Context: Describing a picture of two cats sitting on a chair. ${ }^{2}$

a. saPa mimaw $\mathrm{k}^{\mathrm{w}}$ anač $\quad \theta ə \mathrm{k}^{\mathrm{w}}$ načtən

two cat $\quad$ sit $<$ STAT $>$ chair

'Two cats are sitting on the chair.'

1 The glosses used in this paper as as follows: $3=$ third person, $\mathrm{ABL}=$ ablative, $\mathrm{ACT}$. $\mathrm{INTR}=$ active intransitive, $\mathrm{CNJ}=$ conjunctive, $\mathrm{CONJ}=$ conjunction, $\mathrm{CTR}=$ control transitive, $\mathrm{DET}=$ determiner, $\mathrm{ERG}=$ ergative, $\mathrm{IPFV}=$ imperfective, $\mathrm{MD}=$ middle, $\mathrm{MOD}=$ modal, $\mathrm{NEG}=$ negative, $\mathrm{NMLZ}=$ nominalizer, $\mathrm{PASS}=$ passive, $\mathrm{PL}=$ plural, $\mathrm{POSS}=$ possessive, $\mathrm{PRT}=$ particle, $\mathrm{PST}=$ past, $\mathrm{SBJ}=$ subject, $\mathrm{SG}=$ singular, STAT $=$ stative .

2 Determiners are often ommitted, especially by younger speakers (noted previously in Kroeber 1999; Watanabe 2003; Davis \& Huijsmans 2017; Huijsmans, Reisinger, Lo \& Xu 2018; Mellesmoen 2018). Where determiners are omitted, it is possible to re-insert them in follow up elicitation. We therefore consider them to be elided but underlyingly present, though we do not represent them where they were not produced. 
Pluractionality in Comox-Sliammon

b. saPa məm $\sim$ mimaw $\mathrm{k}^{\mathrm{w}}$ anač $\quad \theta ə \mathrm{k}^{\mathrm{w}}$ načtən

two $\mathrm{C}_{1} \mathrm{C}_{2}$.PL $\sim$ cat sit<STAT> chair

'Two cats are sitting on the chair.'

(2) Context: Picture of a girl in the middle of closing a series of doors.

a. Puk ${ }^{\mathrm{w}}$ to $\sim$ tq-t-as Pimin

all IPFV $\sim$ close-CTR-3ERG door

'She's closing all the doors.'

b. təq $\sim$ təq-t-as Pəm $\sim$ ?imin

$\mathrm{C}_{1} \mathrm{C}_{2}$.PL $\sim$ close-CTR-3ERG $\mathrm{C}_{1} \mathrm{C}_{2}$.PL $\sim$ door

'She's closing the doors.'

While ablaut only marks plurality on verbs, $\mathrm{C}_{1} \mathrm{C}_{2}$ reduplication marks plurality on nouns (1b), verbs (2b) and adjectives (3).

(3) $\quad$ tih $\sim$ tih

$\mathrm{C}_{1} \mathrm{C}_{2}$.PL $\sim$ big

'They are big.'

Though we focus on $\mathrm{C}_{1} \mathrm{C}_{2}$ reduplication and ablaut plurals, these are two out of a rich constellation of plural and pluractional markers in ?ay?ajuசəm, including -V- reduplication, marking temporally distributed events (Mellesmoen 2018), a -Vg- affix marking plural participants (Huijsmans \& Mellesmoen 2018), and -Creduplication, which marks plurality on stative predicates (Mellesmoen To appear).

\section{Background on plurality}

Following previous literature, we assume a boolean structure in the domain of events that is the same as in the domain of individuals (e.g. Krifka 1989, 1992; Landman 2000; Lasersohn 1995; Link 1998). We assume atomic individuals and atomic events, which may be joined by the sum operator $\oplus$. The sum operator $\oplus$ may also join sums of atoms, while a 'part of' relation $\leq$ induces a partial order on both domains, so that both domains form complete join semilattices (Figure 1). ${ }^{3}$

In addition to the domains of individuals and events, we assume structured domains of times and spaces. Trace functions are sum homomorphisms assigning events to the time and space in which they occur (following Krifka 1998). The

3 Whether plurals denote sets or sums is not important for our analysis. Following Lasersohn 1995; Link 1998; Henderson 2012, we could take atomic individuals and atomic events as singleton sets in the powersets of individuals and events (minus the empty set), respectively. In this approach, the sum operator is set union over the powerset, while $\leq$ is set inclusion over the powerset. 


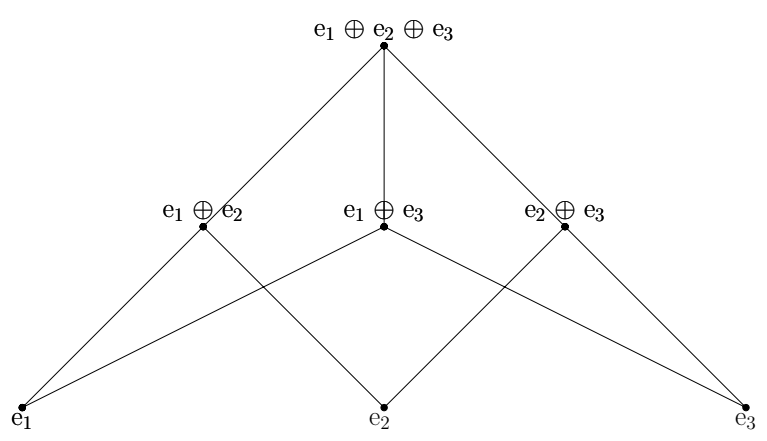

Figure 1 A lattice of events

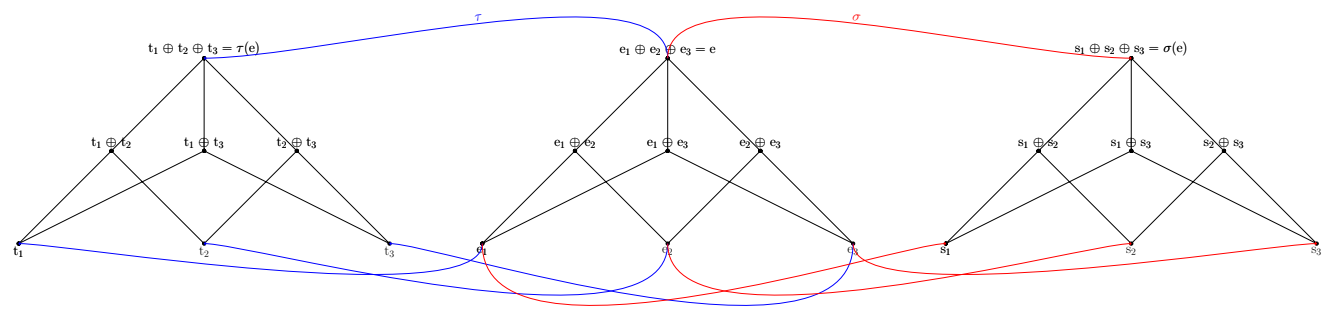

Figure 2 Trace functions (adapted from Henderson 2012: 88)

temporal trace function $\tau$ maps an event to a temporal interval, while the spatial trace function $\sigma$ maps and event to an area of space (Figure 2). ${ }^{4}$

In PayPajuӨəm, the extensions of singular predicates, both nominal and verbal, may be either atomic or sums of atoms. The extensions of pluralized predicates are always non-atomic sums.

In the literature, the division between event-external and event-internal has emerged as the main division between the subtypes of pluractionality. Cusic (1981) originally proposes this division between external and internal pluractionality, which receives a formal analysis in Lasersohn (1995). In Lasersohn (1995), the key difference between event-internal and event-external pluractionality lies in which events are pluralized. In the denotation of an event-external pluractional marker, each event implicated in the plurality is an event that matches the description of the predicate as a whole, while in the denotation of an event-internal pluractional marker,

4 We use the sum $\oplus$ operator for times and spaces, but it might be more accurate to use the material fusion operator + (Link 1983), depending on whether space and time have atomic parts. 


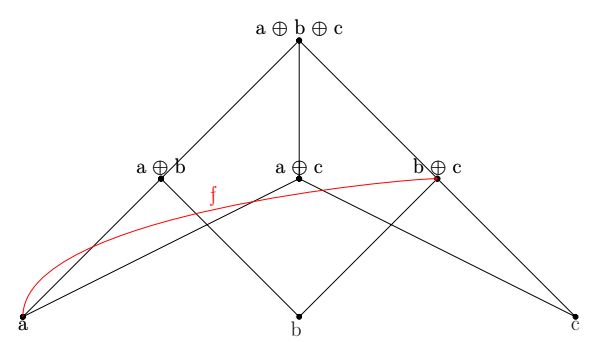

Figure 3 An atomic group individual mapping to its members via the membership function (adapted from Barker 1992: 77)

each event in the plurality is considered to be a phase of the predicate. However, in a cross-linguistic survey of pluractionality, Wood (2007) finds event-internal pluractionals across languages which involve plural events satisfying the predicate.

Wood (2007) proposes that event-internal pluractionals denote a group event, while event-external pluractionals denote an ordinary plurality. Her analysis builds on a treatment of group nouns in Landman 2000, where a grouping operator applies to a set of individuals to create a single set of the set of individuals $(\{\{a, b, c\}\}$,$) .$

Henderson (2012) observes that a range of properties associated with eventinternal pluractionality, including high number of repetitions and high continuity in time, do not fall out straightforwardly from Wood's (2007) analysis. Henderson $(2012,2017)$ proposes that event-internal pluractionals behave in a parallel manner to group nouns like swarm, where the members of the group are required to exist in a particular configuration. In the nominal domain, the individuals must have a high number and be spatially close together in order to satisfy a swarm-type nominal predicate. However, events must have a high number and be temporally close together in order to satisfy a event-internal pluractional predicate. In our discussion of event-internal pluractionals we will build on this analysis, but show that eventinternal pluractionals in Pay?ajüəom do not behave in parallel to swarm-type group nouns, indicating that there is variation in grouping in the verbal domain just as in the nominal domain.

We will follow Henderson $(2012,2017)$ in treating groups as atomic, building on Barker 1992. Barker (1992) proposes that a group is an atomic individual that is constituted by a plurality in order to capture the meaning of nouns like committee, which are singular nouns but typically have a plurality of members. Barker (1992) argues that these nouns denote an atomic individual that is mapped to the individuals that constitute it by a membership function (Figure 3). 


\section{$4 \quad \mathrm{C}_{1} \mathrm{C}_{2}$ Reduplication}

\subsection{Spatio-temporal distribution}

$\mathrm{C}_{1} \mathrm{C}_{2}$ reduplication indicates a sum of events that must be distributed in time and space; this distribution may involve multiple objects (4).
a. $\theta \partial \mathrm{x}^{\mathrm{w}} \sim \theta \partial \mathrm{x}^{\mathrm{w}}-\mathrm{P \partial \textrm {m }}$
$\mathrm{C}_{1} \mathrm{C}_{2}$.PL $\sim$ stab-ACT.INTR

'She is going around stabbing people.'

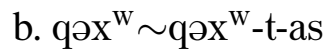

$\mathrm{C}_{1} \mathrm{C}_{2} \cdot \mathrm{PL} \sim$ pound-CTR-3ERG

'He is pounding (multiple piles in).'

c. yəm $\sim$ yəm-t-əm Henry Bruno

$\mathrm{C}_{1} \mathrm{C}_{2}$.PL kick-CTR-PASS Henry Bruno

'Henry is kicking Bruno around.'

Examples (5) and (6) show events must be distributed in time; just spatial distribution is not sufficient. For instance, the locking events must be distributed in time in (5) or use of $\mathrm{C}_{1} \mathrm{C}_{2}$ reduplication is infelicitous, despite the fact that the locking events are distributed in space. Similarly, in (6), the turning-on events are distributed in space across the different lights, but $\mathrm{C}_{1} \mathrm{C}_{2}$ reduplication is only felicitous when the turning-on events are also distributed in time.

(5) Context: I tell you to just wait a moment as we get ready to leave, so I can lock the doors of the house.

\# Context: I press a button on my keys to lock all the doors of my car.

lək $\sim$ ləkl-it $=\check{\mathrm{c}} \quad \mathrm{t} \quad=$ ?imin

$\mathrm{C}_{1} \mathrm{C}_{2}$.PL $\sim$ lock-CTR=1SG.SBJ DET=door

'I'm locking the doors.'

(6) Context: You have a view of a city as it gets dark and see lights coming on, here and there.

\# Context: Streetlights all coming on at the same time.

$\chi^{\mathrm{w}} \partial \mathrm{w} \sim \chi^{\mathrm{w}} \partial \mathrm{w}^{\prime}$

$\mathrm{C}_{1} \mathrm{C}_{2}$.PL $\sim$ turn.on

'They're coming on.' 
Pluractionality in Comox-Sliammon

Examples (7-8) show that events must also be distributed in space; temporal distribution alone is not sufficient. Despite the fact that multiple events of closing occur in (7), the fact that they are in same location means that $\mathrm{C}_{1} \mathrm{C}_{2}$ reduplication is infelicitous. Similarly, $\mathrm{C}_{1} \mathrm{C}_{2}$ reduplication is only felicitous in (8a), where there is spatial distribution of touching events. Multiple touching events that are not distributed in space are not sufficient (8b).

(7) Context: Gloria keeps opening the window, but I find it too cold so I keep closing it.

a. \# təq $\sim$ təq- $\mathrm{t}=\check{\mathrm{c}} \quad \mathrm{t} \quad=$ məmkiyustən

$\mathrm{C}_{1} \mathrm{C}_{2} . \mathrm{PL} \sim$ close-CTR=1SG.SBJ DET=window

'I repeatedly closed the window.'

b. $\check{\text { jaqa }}=\check{\mathrm{c}}=$ gut $\quad$ to $\sim$ tq- $\mathrm{t} \quad$ to $=$ məmkiyuston

$\mathrm{MOD}=1 \mathrm{SG} . \mathrm{SBJ}=\mathrm{PRT}$ IPFV $\sim$ close-CTR DET=window

'I'm forever closing that window.'

(8) a. Context: A child is given a birthday gift, but not allowed to open it yet, so he's feeling it all over to try to guess what's inside.

paya? qәр $\sim$ qәp-t-as

always $\mathrm{C}_{1} \mathrm{C}_{2}$.PL $\sim$ touch-CTR-3ERG

'He's always touching/feeling it.'

b. Context: Your cat is curious about water and always touches it when you fill up his bowl with fresh water. However, he only ever just barely touches it, because he doesn't like to get wet.

paya? $\{$ qə $\sim$ qp-t-as/\#qәp $\sim$ qəp-t-as $\}$ qaya

always IPFV $\sim$ touch-CTR-3ERG/C $\mathrm{C}_{1} \mathrm{C}_{2}$.PL $\sim$ touch-CTR-3ERG water

'He always touches the water.'

In (7)-(8), there is a singular object, raising the question of whether the infelicity of these examples has to do with the inability of the plurality of events to distribute over multiple arguments, rather than the lack of distribution in space. However, predicates pluralized with $\mathrm{C}_{1} \mathrm{C}_{2}$ reduplication are felicitous with singular internal and external arguments, provided it is still possible to distribute the event in space.
a. $\mathrm{hu}=\check{\mathrm{c}} \quad$ Pəm $\sim$ Pimaš $\mathrm{s}=\mathrm{k}^{\mathrm{w}}$ ə⿳亠口了ut
go $=1 \mathrm{SG} . \mathrm{SBJ} \mathrm{C}_{1} \mathrm{C}_{2}$.PL $\sim$ walk NMLZ=morning

'I went for a walk this morning; I went walking about this morning.'

b. Context: Gloria is pushing the chair around the room. 
tay tayq-at-əm Gloria tə $=\theta \partial \mathrm{k}^{\mathrm{w}}$ načtən

$\mathrm{C}_{1} \mathrm{C}_{2}$.PL $\sim$ move-CTR-PASS Gloria DET=chair

'Gloria keeps moving the chair around.'

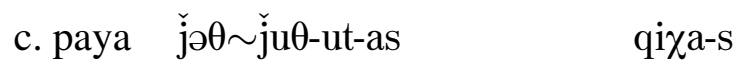

always $\mathrm{C}_{1} \mathrm{C}_{2}$.PL $\sim$ push-CTR-3ERG younger.sibling-3POSS

'He's always pushing his younger sibling around.'

Finally, it is worth noting that the atomic events within the plurality can be adjacent, so that with activities, $\mathrm{C}_{1} \mathrm{C}_{2}$ pluractional may give the impression of one extended, spatio-temporally distributed event (10a), as long as there is distribution in time and space (10b).

a. Context: I walked around campus and back to my residence without stopping.

$$
\begin{aligned}
& \text { Pəm Pim-aš-uł }=\check{c} \quad \text { Piy } \quad \mathrm{x}^{\mathrm{w}} \mathrm{a}=\check{\mathrm{c}} \quad \mathrm{q}^{\mathrm{w}} \mathrm{k}^{\mathrm{w}}-\partial \mathrm{m}=\mathrm{an} \\
& \mathrm{C}_{1} \mathrm{C}_{2} \text {.PL } \sim \text { walk-PST }=1 \mathrm{SG} . \mathrm{SBJ} \text { CONJ NEG }=1 \mathrm{SG} . \mathrm{SBJ} \text { stop-MD }=1 \mathrm{SG} . \mathrm{CNJ}
\end{aligned}
$$

'I went for a walk and I didn't stop.'

b. Context: We're walking from here to the gym...

$$
\begin{aligned}
& \text { \# Pəm } \sim \text { Pimaš }=s ̌ t \\
& \mathrm{C}_{1} \mathrm{C}_{2} . \mathrm{PL} \sim \text { walk=1PL.SBJ }
\end{aligned}
$$

'We're walking.' ( $\checkmark$ for 'We're walking around')

\subsection{Formal analysis}

We analyze $\mathrm{C}_{1} \mathrm{C}_{2}$ reduplication as a kind of event-external pluractionality, adapting the denotation for event-external pluractional markers involving spatio-temporal distribution from Lasersohn (1995: 252). We modify the denotation to require distribution in both time and space, in order to capture the more restricted distribution in PayPajuӨəm because the original denotation required distribution of events in time or space. ${ }^{5}$ Note that the denotation does not rule out distribution over participants,

5 Bar-el (2008) also adapts a version of Lasersohn's (1995) denotation for event-external pluractionals to analyze $\mathrm{C}_{1} \mathrm{C}_{2}$ reduplication in Skwxwú7mesh, another Central Salish language. She does not include requirements for temporal or spatial distribution, however. Instead, she argues that temporal distribution is involved in the interpretation, but as an effect of pluralizing events. She avoids including temporal distribution in the denotation so that the same denotation can also apply where the same reduplication pluralizes nouns. Though we find it necessary to include spatial and temporal distribution requirements in the denotation for event plurality, we will similarly propose that the difference in the interpretation of this morpheme between the nominal and verbal domain arises through differences in the way that entities and events pluralize. 
and may even force it depending on the particular predicate involved since it may be necessary to distribute over participants in order to distribute in space (e.g. closing windows/doors (5), lights turning on/off) (6), but the determining factors are distribution across time and space.

$$
\begin{aligned}
& \llbracket \mathrm{C}_{1} \mathrm{C}_{2} \rrbracket=\lambda \mathrm{e} \lambda \mathrm{P}_{<\varepsilon, t>}\left[* \mathrm{P}(\mathrm{e}) \& \forall \mathrm{e}, \mathrm{e} "\left[\text { atom(e') } \wedge \text { atom(e") } \wedge \text { e' } \leq \mathrm{e} \wedge \mathrm{e}^{\prime \prime} \leq\right.\right. \\
& \left.\left.\mathrm{e} \rightarrow \neg\left[\tau\left(\mathrm{e}^{\prime}\right) \circ \tau\left(\mathrm{e}^{\prime \prime}\right)\right] \& \neg\left[\sigma\left(\mathrm{e}^{\prime}\right) \circ \sigma\left(\mathrm{e}^{\prime \prime}\right)\right]\right]\right]
\end{aligned}
$$

As described in Section 2, Ray?aju $\theta ə m \mathrm{C}_{1} \mathrm{C}_{2}$ reduplication applies in the nominal domain as well as the verbal one. Henderson (2012: 84) proposes that event-external pluractionals in Kaqchikel involve the same type of plural structure found in the domain of count nouns, but the events are individuated through their temporal trace, a mechanism with no counterpart in the nominal domain. This analysis suggests that it should be possible to have a plural marker that applies across the verbal and nominal domains, but with temporal and spatial individuation only being applicable with events. Pay?aju of distinct atoms in both the nominal and verbal domains; however, the temporal and spatial distribution requirements do not apply in the nominal domain. Entities in the plurality can exist at the same time, and distinct atomic entities will trivially satisfy the spatial distribution requirement.
a. mimaw
cat
'cat'
b. məm $\sim$ mimaw
$\mathrm{PL} \sim$ cat
'cats'

$$
\begin{aligned}
& \text { a. } \theta \partial \mathrm{k}^{\mathrm{w}} \text { načtən } \\
& \text { chair } \\
& \text { 'chair' } \\
& \text { b. } \theta \partial \mathrm{k}^{\mathrm{w}} \sim \theta \partial \mathrm{k}^{\mathrm{w}} \text { načtən } \\
& \text { PL } \sim \text { chair } \\
& \text { 'chairs' }
\end{aligned}
$$

This supports the proposal that pluralizing events requires individuation through distribution across time, space, or participants, while the nominal domain does not typically impose such requirements (Henderson 2012, 2017). We therefore propose that the denotation in (11) applies differently in the two domains due to ontological differences in how events and entities exist as distinct atoms. In the nominal domain, $\mathrm{C}_{1} \mathrm{C}_{2}$ reduplication creates a plurality, as in the verbal domain, but the temporal-spatial distribution requirements do not apply.

$$
\llbracket \mathrm{C}_{1} \mathrm{C}_{2} \rrbracket=\lambda \mathrm{x} \lambda \mathrm{P}_{<e, t>}[* \mathrm{P}(\mathrm{x})]
$$




\section{Ablaut: Event-Internal, Grouped Plurals}

Ablaut pluractionals occur with fewer predicate types than $\mathrm{C}_{1} \mathrm{C}_{2}$ pluractionals. They occur with telic predicates and with atelic predicates that involve punctual repeatable events, but not with underived states ${ }^{6}$ or homogeneous activities.

The contrast between ablaut and $\mathrm{C}_{1} \mathrm{C}_{2}$ is most apparent in the inability of the events to distribute over time, space, and participants with ablaut-marked predicates. For instance, multiple cutting events in (15) are not sufficient unless the events are grouped around using up the object; they cannot be distributed over multiple objects (cf. the examples of $\mathrm{C}_{1} \mathrm{C}_{2}$ pluractionals in (5)-(7) above, where each event in the plurality involves a single participant). In (16), the events have a common goal and take place in a shared time and space; if the events are distributed in time, the ablaut pluractional is infelicitous. In (17), the action involves multiple participants acting as group; again, if the events are distributed in time, use of the ablaut pluractional is infelicitous.

(15) $\checkmark$ context 1: There's a piece of paper that's been totally cut into pieces. \# context 2: There's a piece of paper with multiple cuts around the edges. \# context 3: There are different colored ribbons, with a length cut from each.

$\mathrm{k}<\mathrm{a}>$ p-at-as-ut.

cut $<$ ABL.PL $>$-CTR-3ERG-PST

'She cut it up (with scissors).' Root: kəp- 'get cut'

(16) $\checkmark$ context 1: Somebody is punching a punching bag for a workout.

\# context 2: Someone is intermittently punching for someone's attention.

$\lambda<\mathrm{a}>$ s-at-as

get.punched<ABL.PL>-CTR-3ERG

'She punched it up.'

Root: 丸əs- 'get punched'

(17) $\checkmark$ context 1: A flock of ducks coming to the surface.

\# context 2: A swimmer repeatedly coming up for air.

$\grave{\mathrm{p}}<\mathrm{a}>\lambda<\mathrm{i}>\check{\mathrm{s}}$

rise.to.surface $<\mathrm{ABL} . \mathrm{PL}>$

'They surfaced.' /\# 'He keeps surfacing.' Root: pə犭̌̌- 'rise to surface'

6 Ablaut co-occurs with a plural $-\mathrm{C}_{1}$ - reduplicative process in some derived states. It is not clear at this point if this is the same ablaut process found with eventive predicates, see Mellesmoen (To appear) for further discussion. 
Crucially, in all these examples, the subevents belong to a single larger event that is not simply a sum of the individual events. This grouping of events is typical of event-internal pluractionals (Wood 2007; Henderson 2012, 2017).

We adopt an event-internal analysis of the ablaut pluractional marker, proposing it denotes a single event constituted by a plurality of subevents. Unlike in Lasersohn (1995), however, the denotation for ablaut must involve multiple events that satisfy the singular predicate, rather than multiple phases. We propose the denotation in (18), where an atomic event is mapped to the sum of events that constitute it by a contextually-given membership function $f_{i}$, which we propose can be based on notions like shared telos, as well as shared time and space. The sum of events returned by the membership function are events are events satisfying the predicate.

$$
\left.\llbracket<\mathrm{a}>\rrbracket^{\mathrm{g}}=\lambda \mathrm{P}_{<\varepsilon, t>} \lambda \mathrm{e}\left[\operatorname{atom}(\mathrm{e}) \wedge \mathrm{f}_{i}(\mathrm{e}) \leq * \mathrm{P}\right]\right]
$$

The denotation builds on Henderson's (2012) analysis of event-internal pluractionals in Kaqchikel, but is modified in order to avoid placing strict requirements on the number and temporal spacing of events. The Kaqchikel pluractionals that Henderson analyzes involve large numbers of temporally adjacent repetitions; the temporal configuration is thus analogous to the spatial configuration of swarm-type nouns. Ablaut pluractionals in Pay?ajuӨəm may apply to as few as two repetitions of the event and while events may not distribute in time, in the sense of having temporal space between each event, it is still possible for there to be temporal space between some of the events.

(19) Context: Gloria washed two blankets and then hung them out to dry.

$$
\begin{array}{lc}
\mathrm{h}<\mathrm{a}>\mathrm{k}^{\mathrm{w}} \text {-at-əm } & \text { Gloria } \mathrm{Pit}^{\theta} \text { əm } \\
\text { hang.out }<\mathrm{ABL} . P L>-C T R-P A S S & \text { Gloria blanket }
\end{array}
$$

'Gloria hung out blankets.'

(20) Context: Someone cut up a tree. It took him several days to cut it all up.

$$
\begin{aligned}
& \text { Puk }^{\mathrm{w}} \stackrel{\stackrel{\mathrm{c}}{\mathrm{c}}<\mathrm{a}>\mathrm{t} \text {-at-as }}{\text { all }} \text { cut }<\text { ABL.PL }>\text {-CTR-3ERG } \text { wood }
\end{aligned}
$$

'He cut the wood all up.'

This makes them more analogous to committee-type nouns, which do not require a particular spatial configuration or a large number of members. However, subevents of an ablaut pluractional must fall within the temporal-spatial trace of the group event; they do not exist independently in space and time, unlike the individuals constituting a committee-type noun. We take this difference to fall out from the 
ontological differences between individuals, which can exist independently of a group of which they are a part, and events, which cannot.

In some cases, either $\mathrm{C}_{1} \mathrm{C}_{2}$ reduplication or ablaut is possible with the same root. In these cases, $\mathrm{C}_{1} \mathrm{C}_{2}$ reduplication is felicitous where events can be distributed in space and time (21), whereas ablaut is felicitous where events are not distributed but grouped, perhaps through a shared argument or telos, as in (22).

(21) Context 1: Someone cuts a number of ribbons of different colours (one at a time).

\# Context 2: Someone cuts up a single ribbon.

kəp $\sim$ kəp-t-as

$\mathrm{C}_{1} \mathrm{C}_{2}$.PL $\sim$ cut-CTR-3ERG

'She cut them.'

(22) \# Context 1: Someone cuts a number of ribbons of different colours (one at a time).

Context 2: Someone cuts up a single ribbon.

$\hat{\mathrm{k}}<\mathrm{a}>\mathrm{p}$-at-as

cut $<$ ABL.PL $>$-CTR-3ERG

'She cut it up.'

\section{Conclusion}

In this paper, we have discussed how Pay?ajuӨəm pluractionals provide evidence for parallels between plurality in the nominal and verbal domain. In particular, we have argued that event-external pluractionality involves sums of events, while eventinternal pluractionality involves group events, building on Wood (2007); Henderson (2012, 2017). We have shown that ?ay?ajüəm uses the same morpheme, $\mathrm{C}_{1} \mathrm{C}_{2}$ reduplication, to mark plurality in both the nominal and verbal domain, providing morphological evidence for parallel structure in the domain of entities and events. However, $\mathrm{C}_{1} \mathrm{C}_{2}$ reduplication imposes spatial and temporal distribution requirements only in the verbal domain, suggesting that events must be individuated through spatial and temporal distribution in order to form a sum of distinct atoms. ?ay?ajuசəm ablaut pluractionals involve subevents that are not distributed, but grouped into a larger whole, behaving as event-internal pluractionals. However, with ablaut pluractionals, group event membership may be determined through notions like shared telos rather than spatio-temporal configuration. This is more akin to committee-type group nouns than swarm-type group nouns, showing that there is more than one mechanism for grouping in the verbal domain, just as in the nominal domain. 
Pluractionality in Comox-Sliammon

\section{References}

Bar-el, Leora. 2008. Verbal number and aspect in Skwwxwú7mesh. Recherches linguistiques de Vincennes 37. 31-54.

Barker, Chris. 1992. Group terms in English: Representing groups as atoms. Journal of Semantics 9. 69-93. doi:https://doi.org/10.1093/jos/9.1.69.

Cusic, David. 1981. Verbal plurality and aspect: Stanford University PhD dissertation.

Davis, Henry \& Marianne Huijsmans. 2017. Changes in the alignment of arguments in transitive clauses in Pay?ajuөəm (Comox-Sliammon). In 52nd international conference on Salish and neighbouring languages, 13-46. UBCWPL 45.

First Peoples' Cultural Council. 2018. Report on the status of B.C. First Nations languages. Retrieved from http://www.fpcc.ca/files/PDF/Language/FPCCLanguageReport-141016-WEB.pdf.

Henderson, Richard. 2012. Ways of pluralizing events: UC Santa Cruz PhD dissertation.

Henderson, Richard. 2017. Swarms: Spatiotemporal grouping across domains. Natural language and linguistic theory 35. 161-203. doi:https://doi.org/10.1007/s11049-016-9334-z.

Huijsmans, Marianne \& Gloria Mellesmoen. 2018. How to distribute events: Pay?aju日əm pluractionals. In Kimberly Johnson \& Alex Göbel (eds.), SULA 10, $65-78$.

Huijsmans, Marianne, Daniel Reisinger, Roger Lo \& Kaining Xu. 2018. A preliminary sketch of determiners in Pay?ajuөəm. In Wa7 xweysás i nqwal'utteníha $i$ ucwalmícwa: He loves the people's languages. Essays in honour of Henry Davis, Vancouver: UBCOPL.

Krifka, Manfred. 1989. Nominal reference, temporal constitution and quantification in event semantics. In Renate Bartsch, Theo Vennemann \& Johan van Benthem (eds.), Semantics and contextual expression, 75-115. Dordrecht: Foris.

Krifka, Manfred. 1992. Thematic relations as links between nominal reference and temporal constitution. In Lexical matters, 29-54. Stanford: CSLI.

Krifka, Manfred. 1998. The origins of telicity. In Susan Rothstein (ed.), Events and grammar, 197-235. Dordrecht: Kluwer.

Kroeber, Paul. 1999. The Salish language family: Reconstructing syntax. Lincoln: University of Nebraska Press.

Landman, Fred. 2000. Events and plurality: The Jerusalem lectures. Dordrecht: Kluwer Academic.

Lasersohn, Peter. 1995. Plurality, conjunction and events. Dordrecht: Kluwer Academic.

Link, Godehard. 1983. The logical analysis of plural and mass terms: A lattice- 
theoretical approach. In Meaning, use and interpretation of language, 127-146. Berlin: De Gruyter.

Link, Godehard. 1998. Algebraic semantics in language and philosophy. Stanford: CSLI.

Mellesmoen, Gloria. 2018. A one (morpheme) by one (morpheme) approach to pa?apya?: -V?- as a temporal pluractional in infix in Comox-Sliammon. In Marianne Huijsmans, Roger Lo, Oksana Tkachman \& Daniel Reisinger (eds.), 53rd International Conference on Salish and Neighbouring Languages, 143-160.

Mellesmoen, Gloria. To appear. A reanalysis of CV- reduplication in ComoxSliammon. Working Papers of the Linguistics Circle of the University of Victoria. Watanabe, Honoré. 2003. A morphological description of Sliammon, Mainland Comox Salish, with a sketch of syntax ELPR Publications Series AZ-040. Osaka: Osaka Gakuin University.

Wood, Ellen. 2007. The semantic typology of pluractionals: UC Berkeley PhD dissertation.

Gloria Mellesmoen

2613 West Mall

Vancouver, BC V6T 1 Z4

$\cdots$

gloria.mellesmoen@ubc.ca
Marianne Huijsmans

2613 West Mall

Vancouver, BC V6T 1Z4

...

marianne.huijsmans@ubc.ca 